\title{
Prevalence of depression and anxiety disorders in hospitalized patients at the dermatology clinical ward of a university hospital ${ }^{*}$
}

\author{
Prevalência de depressão e ansiedade em pacientes hospitalizados na \\ enfermaria da clínica de dermatologia de um hospital universitário
}

\author{
Maria Rita Polo Gascón ${ }^{1}$ \\ Livia Maria de Araújo Bueno ${ }^{2}$ \\ Mara Cristina Souza de Lucia ${ }^{4}$ \\ Cyro Festa Neto ${ }^{6}$
}

\author{
Cristiana Mara Ribeiro ${ }^{2}$ \\ Glaucia Rosana Guerra Benute ${ }^{3}$ \\ Evandro Ararigbóia Rivitti
}

\begin{abstract}
BACKGROUND: The objective of this study was to estimate the prevalence of depression and anxiety disorders in hospitalized patients at the dermatology ward at a university hospital in São Paulo, Brazil.

Овлестіле: To assess the prevalence of mood and anxiety disorders in hospitalized patients at the dermatology ward at a university hospital in São Paulo.

METHOD: A total of 75 patients, men and women, aged between 18 and 76 years, took part in the research. The study employed a descriptive, cross sectional and correlational method. The data was collected by means of a social demographic questionnaire and the PRIME-MD.

RESULTS: It was found that 45.3 percent of the subjects presented with depressive symptoms, and 52 percent presented with symptoms of anxiety and that this survey showed moderate and high significant correlations $(\mathrm{p}<0,01 ; \mathrm{r}=0,616)$ for depression and anxiety.

CONClusion: These facts could evidence the relationship between physical and psyche, just as the literature presents.

Keywords: Anxiety; Depression; Dermatology; Epidemiology; Psychology

Resumo: Fundamentos: O presente estudo teve como objetivo verificar a freqüência de depressão e ansiedade em pacientes internados na Divisão da Clínica de Dermatologia de um hospital universitário de São Paulo.

OвJетіvo: Avaliar a prevalência de depressão e ansiedade em pacientes hospitalizados na enfermaria da clínica de dermatologia de um hospital universitário em São Paulo.

MÉTODO: Participaram da pesquisa 75 sujeitos, homens e mulheres, entre 18 e 76 anos. O delineamento do estudo foi transversal e descritivo. Os instrumentos utilizados foram Entrevista Sócio Demográfica e PRIME-MD.

RESULTADOS: Identificou-se a presença de depressão em $45,3 \%$ e de ansiedade em $52 \%$ dos pacientes avaliados.

CONCLUSÃo: Verificou-se correlação moderada e altamente significativa $(\mathrm{p}<0,01 ; \mathrm{r}=0,616)$ para os índices de depressão e ansiedade, que pode evidenciar a relação entre adoecimento físico e psíquico muito encontrada na literatura. Palavras-chave: Ansiedade; Depressão; Dermatologia; Epidemiologia; Psicologia
\end{abstract}

Received on 06.05.11

Approved by the Advisory Board and accepted for publication on 28.06.2011.

* Work performed at the Dermatology Clinical Ward of the Hospital das Clínicas of the Faculdade de Medicina of the Universidade de São Paulo (HC-FMUSP) São Paulo (SP), Brazil.

Financial Support: None

Conflict of Interests: None

Master - Psychologist at the Psychology Division of the Instituto Central of the Hospital das Clinicas of the Faculdade de Medicina of the Universidade de São Paulo (ICHC-FMUSP) - São Paulo (SP), Brazil.

In-Hospital Psychology Specialist - Psychology Researcher of the Núcleo de Imunodeficiências Secundárias of the Instituto Central of the Hospital das Clinicas of the Faculdade de Medicina of the Universidade de São Paulo (ICHC-FMUSP) - São Paulo (SP), Brazil.

PhD - Director of the Psychology Research Division of the Instituto Central of the Hospital das Clinicas of the Faculdade de Medicina of the Universidade de São Paulo (ICHC-FMUSP) - São Paulo (SP), Brazil.

PhD - Director of the Psychology Division of the Instituto Central of the Hospital das Clinicas of the Faculdade de Medicina of the Universidade de São Paulo (ICHC-FMUSP) - São Paulo (SP), Brazil.

PhD - Professor at the Universidade de São Paulo (USP) - São Paulo (SP), Brazil.

PhD - Full Professor at the Dermatology Clinic of the Instituto Central of the Hospital das Clinicas of the Faculdade de Medicina of the Universidade de São Paulo (ICHC-FMUSP) - São Paulo (SP), Brazil. 


\section{INTRODUCTION}

The frequency of major mental disorders (such as depression and anxiety) that come to general medical attention has been the subject of much health research. The reason for the growing scientific interest is due to the high prevalence of mental disorders in the population, estimated to be between 12.2 and 48.6 percent, and 20 to 60 percent in hospitalized patients in general hospitals and 30 percent among dermatologic patients. ${ }^{1,2}$

Unfortunately, most of these patients do not have their diagnosis recognized and are not treated. ${ }^{1}$ The estimate is that 55 percent of the patients seen with major depression are not diagnosed; although this estimate rises to 77 percent when generalized anxiety disorders are considered. Some of the principal reasons for the non-recognition of mental disorders are the high probability of these patients reporting only somatic symptoms during the consultation and the doctors' difficulty in recognizing these symptoms as evidence of mental disorders. ${ }^{1}$

A study carried out in 151 patients in a public health outpatients service of a dermatology clinic in the South of the country has found that the frequency of anxiety was 40.39 percent and the frequency of depression was 43.7 percent. $^{3}$ Most of the patients were women (67.5 percent) with low levels of education (68.2 percent having at least completed elementary school), and an average of 55.06 years of age $(\mathrm{DP}=14.75)$.

The prejudices that occur when these disorders are not treated are innumerable and affect many areas of life such as: psychic and somatic suffering, discrimination, social isolation, interruption of studies and work, drug and alcohol abuse, suicide, homicide, self and hetero-aggression, low academic and occupational performance and an increase in mortality. Many studies have shown that these disorders have an important negative impact on the quality of life, even greater than chronic non-psychiatric medical conditions. In the case of dermatologic illnesses, depression is often related to the beginning or the aggravation of skin lesions. ${ }^{2}$

Nowadays there has been an increase in the number of studies which involve the integration between medical and psychological aspects. Psychodermatology is a branch which involves the study and treatment of dermatologic problems which are caused and/or influenced by psychological factors. ${ }^{4,5}$ Many authors write about the relationship between skin and mental conditions due to its importance on the ego construction, presenting the skin as a limiting organ that communicates with the external world. ${ }^{4-9}$

Due to this limiting function, skin disease can cause individual embarrassment. Some authors suggest that, due to the visibility of the lesions, it is diffi- cult for patients not to feel embarrassed, anxious or depressed..$^{8-13}$ Many patients report self-derogatory feelings because, in popular beliefs, dermatologic diseases can be associated with dirt, ugliness and contagiousness, causing social fear, isolation and embarrassment. ${ }^{11}$ Thus, there is an implication between skin diseases and emotional aspects. ${ }^{14,15}$

Therefore, the objective of this study was to estimate the prevalence of mood and anxiety disorders in hospitalized patients in the dermatology ward at a university hospital in São Paulo.

\section{MATERIAL AND METHODS}

A cross sectional study carried out on a representative sample of 75 hospitalized patients in a dermatology division ward at a university hospital in São Paulo, from April to October 2010. The number of patients was calculated based on the quantity of admissions on this ward on the first semester of 2008 (241 admissions), using the conservative estimation of prevalence of psychiatric disorders on internee patients $(30 \%)$, with a confidence interval of $95 \%$. The following were considered exclusive factors: younger than 18 years (legal age) and having any disease that could interfere with cognition. Three instruments were applied within 72 hours of hospitalization: the Mini Mental State Examination, the Social Demographic Questionnaire, and the PRIME-MD.

The Mini Mental State Examination (MEN) is an instrument widely used to trace cognitive compromise. ${ }^{16}$ The exam is much used in clinics and research for detecting cognitive losses, disease follow-up and monitoring treatment response. The instrument is composed of the following items: questions that assess temporal orientation, spatial orientation, shortterm memory, calculation and attention. This instrument was used to screen and determine whether or not to include patients in the study.

The social demographic questionnaire is composed of 14 questions on demographic data (such as sex, age, civil state, and profession), three clinical questions: diagnosis, duration of treatment and number of hospitalizations, and one open question about life changes after the disease appeared.

The PRIME-MD is an instrument that facilitates the accurate and rapid recognition and diagnosis of mental disorders; it is the most frequently employed instrument for adults and primary attention services. ${ }^{17}$ PRIME-MD utilizes standard questions that directly focus key diagnostic symptoms and also a decisiontree model that facilitates the differential diagnosis. In this study, the Mood Module and Anxiety Module of the instrument were used to achieve the objectives.

The results of the social-demographic, clinical 
and PRIME-MD variables were submitted to an exploratory analysis, obtaining Frequency, Average, Standard Deviation and parametric test (Pearson's r), correlating the social-demographic and clinical variables to depression and anxiety results by means of the SPSS 13.0 program, with $\mathrm{p}<0.05$ considered significant association. The project was approved by the Ethics Committee of the Institution.

\section{RESULTS}

The sample was composed of 75 patients, most of them female ( $47-62.6$ percent). The average age was 44.5 years, varying from 18-76 years (Standard Deviation $(\mathrm{SD})=16$ years). The main social-demographic characteristics are depicted on table 1.

TABLE 1: Distribution of patients according to social demographic data. Results Social Demografic

\begin{tabular}{|c|c|c|}
\hline Characteristics & $\mathbf{N}$ & $\%$ \\
\hline \multicolumn{3}{|l|}{ Gender } \\
\hline Male & 28 & 37,3 \\
\hline Female & 47 & 62,6 \\
\hline \multicolumn{3}{|l|}{ Age } \\
\hline $18-29$ years & 17 & 22,6 \\
\hline $30-39$ years & 10 & 13,3 \\
\hline $40-49$ years & 20 & 26,6 \\
\hline $50-59$ years & 11 & 14,6 \\
\hline $60-69$ years & 12 & 16 \\
\hline 70- 76 years & 5 & 6,6 \\
\hline \multicolumn{3}{|l|}{ Schooling } \\
\hline $0-4$ years & 23 & 30,6 \\
\hline $5-8$ years & 15 & 20 \\
\hline $9-11$ years & 24 & 32 \\
\hline More than 11 years & 13 & 17,3 \\
\hline \multicolumn{3}{|l|}{ Marital State } \\
\hline Single & 25 & 33,3 \\
\hline Married & 25 & 33,3 \\
\hline Widow & 8 & 10,6 \\
\hline Living Togheter & 12 & 16 \\
\hline Divorced & 5 & 6,7 \\
\hline \multicolumn{3}{|l|}{ Color } \\
\hline Asian & 1 & 1,3 \\
\hline White & 49 & 65,3 \\
\hline Brown & 18 & 24 \\
\hline Black & 7 & 9,4 \\
\hline \multicolumn{3}{|l|}{ Family Income } \\
\hline Less than $1 \mathrm{MW}^{*}$ & 6 & 8 \\
\hline $1-5 \mathrm{MW}$ & 59 & 78,6 \\
\hline $6-10 \mathrm{MW}$ & 8 & 10,6 \\
\hline More than $10 \mathrm{MW}$ & 2 & 2,6 \\
\hline \multicolumn{3}{|l|}{ Occupation } \\
\hline Employed & 39 & 52 \\
\hline Unemployed & 13 & 17,3 \\
\hline Housewife & 10 & 1,3 \\
\hline Retired & 13 & 17,3 \\
\hline
\end{tabular}

*MS: Minimum Wage $(\mathrm{R} \$ 510,00)$
The most prevalent dermatologic diseases were: psoriasis (18.6 percent), skin lesions under clinical investigation (14.6 percent), lupus (9.3\%), eczema (8 percent), pemphigus vulgaris (6.6 percent), Leprosy (5.3 percent) and epidermolysis bullosa, vasculitis and scleroderma with 4 percent each. The average time for dermatologic disease evolution was 68 months, with an average of two hospitalizations.

Most of the patients (21.3 percent) reported the onset of symptoms 10 years ago and were on their first hospitalization (58.7 percent). The table with clinical data is attached below (Table 2).

The frequency of depression was 45.3 percent and of anxiety was 52 percent.

There were no correlations between mood and anxiety disorders and the variables (sex, age, civil state, family income, schooling, time of evolution of disease and number of hospitalizations).

The table with prevalence of mood and anxiety disorder data is attached below (Table 3).

TABLE 2: Distribution of patients according to clinical characteristics

\begin{tabular}{lll}
\hline $\begin{array}{l}\text { Variable } \\
\text { Time of Disease }\end{array}$ & $\mathbf{N}$ & $\%$ \\
\hline Less than a month & 14 & 18,7 \\
1 a 6 months & 12 & 16 \\
1 a 3 years & 5 & 6,7 \\
3 a 5 years & 18 & 24 \\
5 a 10 years & 10 & 13,4 \\
More than 10 years & 16 & 21,3 \\
& & \\
Hospitalizations & 44 & 58,7 \\
$1^{\mathrm{a}}$ & 13 & 17,3 \\
$2^{\mathrm{a}}$ & 5 & 6,7 \\
$3^{\mathrm{a}}$ & 7 & 9,3 \\
$4^{\mathrm{a}}$ & 2 & 2,7 \\
$5^{\mathrm{a}}$ & 1 & 2,7 \\
$6^{\mathrm{a}}$ & 1 & 2,7 \\
$10^{\mathrm{a}}$ & 1 & 2,7 \\
$15^{\mathrm{a}}$ & & \\
\hline
\end{tabular}

TABLE 3: Prevalence of Depression and Anxiety

\begin{tabular}{lll}
\hline Disorder & N & $\%$ \\
\hline Depression & & \\
Yes & 34 & 45,3 \\
No & 41 & 54,6 \\
Anxiety & & \\
Yes & 39 & 52 \\
No & 36 & 48 \\
\hline
\end{tabular}


A statistical correlation between depression and anxiety $(\mathrm{p}<0.01, \mathrm{r}=0.616)$ was found, so the patient who presented a depressive mood tended to present signs and symptoms of anxiety as well.

The main depressive symptoms in patients diagnosed with depression were: depressed mood, fatigue, loss of energy, insomnia or hypersomnia, guilt and uselessness.

The table with the distribution of depressive symptomatology in the patients is shown below (Table 4).

Jitters, anxiety or inquietude, insomnia, wakefulness after little sleep, irritability and boredom were the principal symptoms reported by patients with an anxiety diagnosis. The table with the distribution of anxiety symptomatology in the patients is attached below (Table 5).

Concerning the changes that occurred after the appearance of the skin disease, most of the patients reported a negative body and self-image perception. Patients reported feelings of inadequacy, sadness and low self-esteem. The curiosity and annoyance brought on by other people's fear of contagion caused feelings of shame and discomfort, leading the person to social isolation and prejudice in professional and social areas. The changes that occurred after the appearance of skin disease are attached below (Chart 1).

\section{DISCUSSION}

This study has found that the frequency of anxiety was greater than the frequency of depression in hospitalized patients in the Dermatology Clinic Ward studied. This outcome was different from a study with dermatologic patients on the South of the country. ${ }^{3}$ The general results found corroborated those of the literature in which the prevalence of theses disorders in a general hospital ward are 20 percent to 60 percent. ${ }^{1}$
CHART 1: Self-reported changes after skin diseases

\begin{tabular}{|ll|} 
Humor alteration & 31 \\
Stigma/Bias & 23 \\
$\begin{array}{l}\text { Alteration of self-image } \\
\text { perception }\end{array}$ & 20 \\
Alteration of routine of daily & \\
activities of life and leisure & 20 \\
Prejudice at work & \\
Presence of pain & 18 \\
No changes reported & 8 \\
\hline
\end{tabular}

The prevalence of anxiety and depression were neither correlated to social-demographic questions (sex, age, familiar income, occupation) nor to clinical conditions (time of evolution of the disease and number of internments). They were correlated to negative impact caused by the skin disease on functionality and quality of life, since it is exposed and visible, influencing self-perception and social relations.

We were able to observe in our literature review that the visibility of skin lesions causes embarrassment, sadness, shame and anxiety., ${ }^{6,10,11,15}$ This study was able to prove this fact by the number of reports about changes in lives after the onset of skin disease, concomitant to the presence of mood and anxiety disorders. ${ }^{2}$ The frequency of depression in patients with skin diseases in the literature (30 percent) was 10 percent smaller than the one found in this study.

These patients also reported stigma and bias because of their skin diseases. On common thought, skin disease is related with dirt, ugliness and contagiousness, which surely can be the cause of avoidance by others. After the onset of the skin disease, a negative perception of the body image was found in these patients. ${ }^{15}$ These data corroborate that of another study that reported self-derogatory feelings in patients with skin diseases, along with social isolation, fear and shame. ${ }^{2,14,15}$

TABLE 4: Distribution of depressive symptoms, according to the presence or absence of a diagnosis of depression

\begin{tabular}{|c|c|c|c|c|}
\hline \multirow{2}{*}{$\begin{array}{l}\text { Depressive } \\
\text { Imnsomia or Hypersomnia }\end{array}$} & \multicolumn{2}{|c|}{$\begin{array}{l}\text { Patients with } \\
\text { Symptomatology } \\
\text { diagnosis }(\mathrm{N}=34)\end{array}$} & \multicolumn{2}{|c|}{$\begin{array}{l}\text { Patients without } \\
\text { depression depression } \\
\text { diagnosis }(\mathbf{N}=41)\end{array}$} \\
\hline & 29 & $(85,2 \%)$ & 18 & $(43,9 \%)$ \\
\hline Fatigue or loss of energy & 30 & $(88,2 \%)$ & 16 & $(39,0 \%)$ \\
\hline Decrease or Increase in appetite & 21 & $(61,7 \%)$ & 14 & $(34,1 \%)$ \\
\hline Less interest on daily life activities & 26 & $(76,4 \%)$ & 6 & $(14,6 \%)$ \\
\hline Depressed humor & 32 & $(94,1 \%)$ & 4 & $(9,7 \%)$ \\
\hline Feelings of inutility or guilt & 29 & $(85,2 \%)$ & 7 & $(17,0 \%)$ \\
\hline Decrease of concentration & 19 & $(55,8 \%)$ & 7 & $(17,0 \%)$ \\
\hline Psychomotor Agitation or Retardation & 30 & $(88,2 \%)$ & 11 & $(26,8 \%)$ \\
\hline Frequent death thoughts & 19 & $(55,8 \%)$ & 3 & $(7,3 \%)$ \\
\hline
\end{tabular}


TABLE 5: Distribution of anxiety symptoms, according to presence or absence of a diagnosis of Anxiety

\begin{tabular}{lll}
\hline Anxiety Symptomatology & $\begin{array}{l}\text { Patients with anxiety } \\
\text { diagnosis(N=39) }\end{array}$ & $\begin{array}{l}\text { Patients without anxiety } \\
\text { diagnosis (N=36) }\end{array}$ \\
\hline Jitters, Anxiety or Inquietude & $38(97,4 \%)$ & $10(27,7 \%)$ \\
Psychomotor Agitation & $28(71,7 \%)$ & $1(2,7 \%)$ \\
Loss of energy & $33(84,6 \%)$ & $3(8,3 \%)$ \\
Presence of muscle tension & $32(82,0 \%)$ & $2(5,5 \%)$ \\
Difficulty to fall asleep or to keep sleeping & $35(89.7 \%)$ & $2(5,5 \%)$ \\
Decrease of concentration & $23(58,9 \%)$ & $1(2,7 \%)$ \\
Irritability and Discomfort & $35(89,7 \%)$ & $7(19,4 \%)$ \\
\hline
\end{tabular}

\section{CONCLUSION}

According to the data found in this study it was possible to observe that the frequency of mood and anxiety disorders in hospitalized patients at the dermatology ward was 52 percent for anxiety and 45.3 percent for depression. These frequencies were not correlated to clinical or social-demographic variables; however they were correlated to negative impact on functionality and quality of life caused by the skin disease. This fact emphasizes the importance of multidisciplinary teams in the attention to patients in general hospitals due to the high co-morbidity with psychiatric disorders.

Finally, it is important to highlight that the experiment planning of this study was cross sectional and exploratory, which enabled us to verify the prevalence of mood and anxiety disorders in dermatologic patients at a specific moment only. Studies that verify if early detection and monitoring of these symptoms can improve the quality of life and prognosis of these patients are quite necessary.

\section{REFERENCES}

1. Botega NJ, Bio MR, Zomignani MA, Garcia Jr C, Pereira WAB. Transtornos do humor em enfermaria de clínica médica e validação de escala de medida (HAD) de ansiedade e depressão. Rev. Saúde Pública. 1995;29:359-63.

2. Fried R, Gupta M, Gupta, A. Depression and Skin Diseases. Dermatol Clin. 2005;23:657-64.

3. Ludwig MWB, Redico LB, Zogbi H, Hauber L, Fachin TH, Muller MC. Aspectos psicológicos em dermatologia: avaliação de índices de ansiedade, depressão, estresse e qualidade de vida. Psic Rev Psicol Vetor Ed. 2006;7:69-76.

4. Hoffmann FS, Zogbi H, Fleck P, Muller MC. A integração mente e corpo em Psicodermatologia. Psicol Teor Prát. 2005;7:51-60.

5. Koo J, Lebwohl A. Psycho dermatology: the mind and skin connection. Am Fam Physician. 2001;64:1873-8.

6. Anzieu D. 0 Eu - pele. São Paulo: Casa do Psicólogo; 1989

7. Montagu A. Tocar: o significado humano da pele. São Paulo: Summus; 1988.

8. Winnicott DW. 0 ambiente e os processos de maturação. Porto Alegre: Artmed; 1983.

9. Alves CJM, Martelli ACC, Prado RBR, Fonseca MS. Variabilidade de diagnósticos psicológicos frente à avaliação dermatológica da escoriação psicogênica. An Bras Dermatol. 2009;84:534-7.

10. Strauss G. Skin disords. Baltimore: Williams Wilkins; 1989

11. Ludwig MWB, Oliveira MS, Muller MC, Gonçalves AMBF. Localização da lesão e níveis de stress em pacientes dermatológicos. Estud Psicol.2008;25:343-52.
12. Fonseca G.F, Campos LC. Vitiligo. Acta Médica. 2003;24:644-53.

13. Azulay RD, Azulay DR. Dermatologia. Rio de Janeiro: Guanabara Koogan; 1992.

14. Moffaert M. Psychodermatology: an overviem. Psychother Psychosom. 1992;58:125-36.

15. Naldeson, T. A person's boudaries: a meaning of skin disease. Cutis. 1972;21:90-3

16. Folstein MF, Folstein SE, McHugh PR. "Mini-mental state": a pratical method for grading the cognitive state of patients for clinician. J Psychiatric Res. 1975;12:189-98.

17. Fraguas R Jr, Henriques SG Jr, De Lucia MS, Iosifescu DV, Schwartz FH, Menezes $\mathrm{PR}$, et al. The detection of depression in medical setting: A study with PRIME-MD. J Affect Disord. 2006;91:11-7.

\author{
MAILING ADDRESS: \\ Maria Rita Polo Gascón \\ Rua Saturnino dos Santos, 224 Ipiranga \\ 04124-150 São Paulo, SP \\ E-mail:mariaritapolo@botmail.com
}

How to cite this article: Gascón MRP, Ribeiro CM, Bueno LMA, Benute GRG, de Lucia MCS, Rivitti EA, Festa Neto C. Prevalence of depression and anxiety disorders in hospitalized patients at a dermatology clinical ward of a university hospital. An Bras Dermatol. 2012;87(3):403-7. 